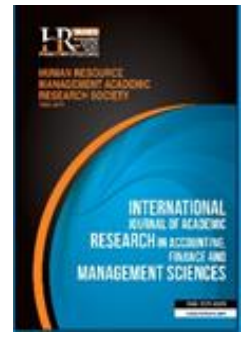

International Journal of Academic Research in Accounting, Finance and Management Sciences

Vol. 10, No.3, July 2020, pp. 10-19

E-ISSN: 2225-8329, P-ISSN: 2308-0337

(c) 2020 HRMARS

www.hrmars.com

To cite this article: Osei-Kuffour, F., Peprah, W. K. (2020). Correlate of Income Diversification and Financial Sustainability of Private Tertiary Institutions as Moderated by Institutional Profile, International Journal of Academic Research in Accounting, Finance and Management Sciences 10 (3): 10-19.

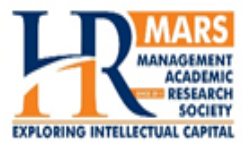

\title{
Correlate of Income Diversification and Financial Sustainability of Private Tertiary Institutions as Moderated by Institutional Profile
}

\author{
Francis Osei-Kuffour ${ }^{1}$, Williams Kwasi Peprah ${ }^{2}$ \\ ${ }_{1,2}$ School of Business, Valley View University, Accra, Ghana, \\ ${ }^{1}$ E-mail: fkuffour@vvu.edu.gh, ${ }^{2} E$-mail: williams.peprah@vvu.edu.gh
}

\begin{abstract}
In our world today, financial sustainability challenges of Private Tertiary Institutions (PTIs) reverberate far and wide as a result of limited resources caused by reductions in state support in funding higher education and dwindling enrolments. These situations limit mission achievements. There are many predictions of PTIs closure due to mounting deficits. Calls for government assistance are not yielding any results as increasing demographic diversity has correlated to decreasing financial support from governments. Given this phenomenon, this study looked at the correlate of income diversification and financial sustainability of private tertiary institutions as moderated by institutional profile. The study utilized parametric inferential statistics by relying on regression Process v3.2 by Andrew F. Hayes model 1. The study was carried out in private tertiary institutions in the Greater Accra Region of Ghana. Fourty out of the Sixty PTIs in the Region were, randomly sampled to answer the self-constructed questionnaires with the Cronbach Alpha of .863 for income diversification and .852 for financial sustainability. The study revealed a positive and moderate relationship between income diversification and financial sustainability. Income diversification predicted financial sustainability by $17.6 \%$. There was a significant enhancing moderating effect of institutional profile on income diversification and financial sustainability relationship. Denominational PTIs relied more on income diversification for financial sustainability than Non-denominational PTIs. The study, therefore, recommends that the PEIs invest in profitable income diversification ventures. The study further recommends for future studies to identify the other $82.40 \%$ variables that can help to explain financial sustainability of PEIS.
\end{abstract}

Key words Income Diversification, Financial Sustainability, Institutional Profile, Private Tertiary Institutions

\begin{tabular}{|c|c|c|}
\hline Received: & 18 Jun 2020 & (C) The Authors 2020 \\
\hline Revised: & 22 Jul 2020 & Published by Human Resource Management Academic Research Society (www.hrmars.com) \\
\hline $\begin{array}{l}\text { Accepted: } \\
\text { ed Online: }\end{array}$ & $\begin{array}{l}30 \text { Aug } 2020 \\
04 \text { Sep } 2020\end{array}$ & $\begin{array}{l}\text { This article is published under the Creative Commons Attribution (CC BY } 4.0 \text { ) license. Anyone may } \\
\text { reproduce, distribute, translate and create derivative works of this article (for both commercial and } \\
\text { non-commercial purposes), subject to full attribution to the original publication and authors. The full } \\
\text { terms of this license may be seen at: http://creativecommons.org/licences/by/4.0/legalcode }\end{array}$ \\
\hline
\end{tabular}

\section{Introduction}

Private Tertiary Institutions (PTIs) are currently experiencing financial sustainability challenges. These challenges limit them in achieving their missions and their ability to deliver top-notch educational services and opportunities for learners to harness their full potential in various disciplines. Problems of financial sustainability of educational institutions in general reverberate far and wide as costs of providing quality education continue to increase significantly in times of decreasing governmental support and dwindling enrolment (Marginson, 2017; Wu, 2017). Afriyie (2015) cites the closure of Atlantic Union College, the first Adventist College in the United States of America established in 1883, in August 2011 due to financial sustainability challenges. Wu (2017) cites the closure of Burlington College, a private tertiary institution in the same country as a result of financial crises. On average, over 104 private tertiary institutions closed between 2004 and 2012 in the United States of America as a result of financial sustainability challenges (Greenwell, 2017). 
Private tertiary institutions in the Philippines have had a long cry for assistance to remain financially sustainable (Serafica, 2018). Private tertiary institution in Malaysia are considering other means of generating income to avoid collapse due to reductions in government's support (Mujani \& Yaakub, 2017). Private tertiary institutions in Brazil are experiencing mass redundancies of teachers, cuts in wages and quality instructional issues as a result of financial sustainability challenges (de Jesus \& Dubeux, 2018).

In Africa, private tertiary institutions face varied financial difficulties. Mugo \& Ngahu (2015) observe that many PTIs in Kenya have folded-up entirely as a result of their inability to support themselves financially. University managers recently warn that Kenya's public universities will be shut down due to rising debts as universities owe more than Sh7 billion in agency fees and another Sh4 billion in salary arrears [\$67,521,945 and $\$ 38,583,968$, respectively (exchange rate as at March, 2020)] (Oduor, 2018).

In Nigeria, Ahmed (2015) notes that PTIs lack the resources that are expected to propel them to achieve their goals. In Ghana, many PTIs are running on life support (Addo, 2018). A private publicly traded tertiary institution was mandated by its shareholders to lay-off 40 percent of staff as a result of inadequate finances (Mynewsgh, 2018).

The traditional source of revenue (tuition fees) of PEls is decreasing due to severe competitions from public educational institutions. Almost all the heads of private educational institutions are expressing worries on the current trend of enrolment competition because they require significant effort to admit, at most, 1,000 students in a given academic year (GNA, 2017; Donkor, 2017; Siaw, 2018; Bediako, 2019).

The problem of over-reliance on the traditional source of revenue by the PEIs has further been made bear by the emergence of the corona virus (COVID 19) in recent times. One of the hardest hit sectors in the Ghanaian economy is education. The government ordered the suspension of various activities, including education, in a bid to stem the spread of the virus (Dogbey, 2020). The pandemic exacerbated the financial burden of the private educational institutions which needed to pay its employees despite the break in tuition payments. The institutions needed to appeal to the government for support because most of them could not pay the salaries of their employees (Quartey, 2020; Dogbey, 2020).

Many educational experts are predicting the closure of more private tertiary institutions before 2028 (Alhassan, 2017; Eide, 2018; Horn, 2018; Citifmonline, 2018). These predictions call for a concerted efforts to address the financial sustainability challenges of PTIs because these institutions make significant impacts on the socio-economic development of world economies by expanding access to quality higher education (Yanka, 2017). Various studies have looked at the financial sustainability of tertiary institutions (Afriyie, 2015; Cernostana, 2017; Kharusi \& Murthy, 2017; Njeri et al., 2017; Ekpoh \& Okpa, 2017; Cernostana, 2018). None of these studies considered the moderating effect of institutional profile. Again, all these studies appeared to have been carried out outside Ghana. The present study sort to address these gaps by extending the financial sustainability discourse into Ghana by considering a moderating effect of institutional profile on financial sustainability of PTIs. As a result, the study sorts to answer the following questions:

1. Is there a significant relationship between income diversification and financial sustainability?

2. Does institutional type moderate the relationship between income diversification and financial sustainability when considering:

a. Denominational Institution

b. Non-denominational Institution

The null hypotheses of the study were:

1: There is no significant relationship between income diversification and financial Sustainability.

2: Institutional profile does not moderate the relationship between income diversification and financial sustainability when considering:

c. Denominational Institution

d. Non-denominational Institution

\section{Literature review}

\subsection{Income diversification}

León (2001), in the four pillars of the financial sustainability concept, refers to income diversification as the number of income sources that provide organizational funding. León argues that 60 percent of an 
institution's total budget needs to come from five different income sources instead of relying solely on a single source, which, in an unexpected variation, may induce financial challenges. According to the concept, an institution's income generation is a medium that promotes and allows the institution to diversify its revenue sources into various activities such as sale of goods and services, rental services, corporate alliances, business-related corporations, etc., and have access to unrestricted income for day-to-day operational activities (ljeoma et al., 2018).

Ekpoh \& Okpa (2017) consider income diversification as the creation of additional income besides the primary income source through new unrelated revenue sources that add to the pool of income available to an institution for operations. The researchers indicate that for educational institutions to survive in the long-term, strategies to diversify funding sources to bring in additional revenue to address various demands by stakeholders and expand resources base for survival and success, are imperative. Fentahun et al. (2018) note that income diversification deals with the process of diversifying revenue portfolios and making use of a diverse mixture of resources and assets to achieve a required need, improve performance and manage risk. The researchers note that individuals and organizations do not collect all their income from a single source or hold asset and use their assets in one portfolio, hence concluded that diversification is the norm for continued growth and survival.

Agyeman et al. (2014) posit that by inclining to the diversification of institutional activities within and outside, the institution addresses income security shortfalls that supports and accumulates income for institutional expansion, engagement in non-traditional businesses and opens avenues to expand revenue base that helps to solve current and long-term financial sustainability challenges. Salam et al. (2019) allude that institutions should pay attention to various income diversification tactics which are differentially accessible to them since diversification of income sources is said to yield advantages as it reduces idiosyncratic risks arising from market conditions. The researchers argue that concentration strategy limits diversification and increases risk. Income diversification, operationally, involves a strategy to incorporate ventures, interest income and donor support as additional income sources for operational activities.

Nyamwega (2016) is of the view that institutional ventures involve all other income-generating activities, besides the core activities, which an institution can undertake to raise extra revenue to supplement the income from core activities. The researcher adds that institutional ventures may include; school buses services, farming, hiring of classroom for use by the public, clubs and societies, production of goods, etc. Miranda et al. (2016) observe that tuition and other fees alone may not be able to address the increasing needs of educational institutions' clientele due to limited inflow in annual budgets. The researchers add that the emergence of income-generating ventures in the University of Eastern Philippines is an answer to resource mobilization strategies needed to support and fill in budget gaps to cover university expenditure.

Amos \& Koda (2018) assert that various income-generating activities by educational institutions enable them to cope with unexpected decline in mainstream revenue without necessarily transmitting the shock to stakeholders. The researchers add that additional funds generated through institutional ventures aid in the acquisition of various materials needed for teaching and learning and other maintenance works. Krasulia (2014) assert that managers of educational institutions all over the world face the task of obtaining adequate funding necessary to finance teaching, research, and other operational service needed for the smooth running of their institutions. The researcher notes that under conditions of financial stress, donor support is considered an essential source of income for institutions that requires careful management and utilization.

\subsection{Financial sustainability}

Afriyie (2015) notes that financial sustainability deals with an institution's ability to diversify its revenue sources by recognizing and evaluating the totality of its cost to remain viable and remain in business, now and into the future. Wachira (2018) adds that financial sustainability involves an institution's ability to create sufficient funds to meet the cost of its current operations as well as future commitments without impairments in its future activities. In the four pillars of financial sustainability concept, León (2001) notes that efficient procedures for administration and finances, fiscal planning, in conjunction with strategic planning, income diversification, and institutional own income generation determine the sturdy 
state of an organization's financial sustainability. The concept further alludes that financial sustainability involves the ability of an organization to generate revenue to meet demands to maintain productive processes at a constant or increasing pace to achieve outcomes and surplus (Pop, 2019).

Financial sustainability involves looking at key financial ratios such as profitability, liquidity, activity/assets management, and financial stability in terms of total debts ratio, equity ratio, debt to equity ratio and debt service coverage ratio (Wijewaradana \& Munasinghe, 2015; Institute of Chartered Accountants, Ghana [ICAG], 2015; Kharusi \& Murthy, 2017; Association of Chartered Certified Accountants [ACCA], 2017; Cernostana, 2017, 2018) to measure financial stability of institutions which allow them to assess their current financial health, either year-by-year or by an established industry benchmark. Cash flow levels also aid an institution to measure and evaluate its strength and stability because the survival of an institution is dependent on the availability of cash to meet financial obligations on time (Stice et al., 2017).

Financial viability denotes an institution's financial condition, which highlights a favorable income to expenditure ratio and efficient utilization of resources in operational activities within the standard weight of environmental factors (Koleda \& Oganisjana, 2015). Water \& Sanitation for the Urban Poor [WSUP] (2018) believes that institutions are expected to fulfil their mandates in the provision of goods and services to customers. This mission gets accomplished by the development of financially viable service delivery models, which ultimately underpin long-term sustainability by generating revenues to facilitate cost recovery for the institutions. Khan et al. (2017) look at financial self-sufficiency as a measure of how well an organization earns from all internally generated revenue after covering all its expenditures. The researchers further note that full sustainability of organizations depends on higher self-sufficiency, which calls for management to direct much attention to financial autonomy, the extent of operating revenue in covering the cost of operations.

Harelimana (2017) asserts that financial self-sufficiency is the ability of an institution to operate without outside support or subsidization. Accordingly, financially self-sufficient operation is seen as a situation where all operational and other expenses, as a result of past or present events, are fully considered and covered by self-generated revenue of an institution. Esampally \& Joshi (2016) add that financial self-sufficiency indicates whether an institution earns sufficient operating revenue to cover total expenses. Pavlov \& Katsamakas (2019) note that a decreasing trend in enrolment is equivalent to an operating deficit, especially at tuition-dependent educational institutions. The study asserts that reduction in admissions and its resultant drop in income leads to annual shortages which may continue to escalate without pragmatic diversification strategies. The researchers further assert that 20 percent drop in students' enrolment at Hampshire College in Amherst, United States, resulted in a reduction in revenue of 18.33 percent within five years, from $\$ 60$ million to $\$ 49$ million. This indicates that downward enrolment trend influences long-term financial sustainability of educational institutions. In an environment where dwindling enrolment is the order of the day, diversification strategies become eminent.

\subsection{Income Diversification and Financial Sustainability}

Ekpoh \& Okpa (2017) looked at diversification of sources of funding university education for sustainability, its challenges, and strategies for improvement. The study sampled 480 respondents from four federal universities in the South-South region of Nigeria. Findings indicated that diversifying university income to include consultancy services, commercialization of physical facilities, part-time degree programs, proper financial management, and eliminating poor attitude of staff increased enrolment with its resultant positive effect on the financial sustainability of universities in the South-South region of Nigeria.

Amos \& Koda (2018) studied the contribution of school-based income-generating activities in quality education provision in secondary schools managed by the Catholic Diocese of Moshi in Tanzania. The study sampled 252 respondents from 12 secondary schools operated by the Catholic Church. The study concluded that institutional ventures are essential alternative means of generating additional income as they enable second cycle institutions to solve financial problems. The study listed crop farming, vegetable, and poultry farming as the significant ventures managed by the schools.

Nyamwega (2016) evaluated income-generating projects in public secondary schools in Nairobi County. The researcher sampled 11 second cycle public institutions. The study revealed that the schools 
earned between KShs 680,000 and $K S h s 6,000,000(\$ 6,559$ and\$57,876 respectively [exchange rate as at March, 2020]) per year from ventures, an indication that school-based ventures are profitable. The study concluded that institutional managers should be more innovative in initiating more institutional ventures to stay financially sustainable.

In a study conducted by Adan \& Keiyoro (2018) on factors influencing the implementation of incomegenerating projects in public secondary schools in Isiolo, Kenya, the study found that institutional ventures enhance financial sustainability as it enables educational institutions to cope with the financial dynamics without, necessarily, transferring budget overruns to parents and guardians. The researchers, therefore, called on management to equip those charged with the responsibility of ensuring the viability of incomegenerating activities in secondary schools in Isiolo North Sub- County, Kenya.

\subsection{Institutional profile}

Institutional profile, used as a moderator in this study, describes the institutional ownership, grouped under denominational and non-denominational. Institutional differences loom on this study and knowledge of each institution becomes vital as the schools may vary in terms of ownership. Studies have found that institutional profile has an influence on the financial sustainability of institutions (Kisengo \& Kombo, 2014; Hossain \& Khan, 2016; Lambinicio, 2016; Ibrahim, 2019).

Sakawa \& Watanabel (2020) found that strategic and monitoring roles of institutional owners strengthen institutions for higher growth opportunities, thereby contributing to enhancing institutional sustainability. The researchers examined institutional ownership and firm performance under stakeholderoriented corporate governance in Japan using 2924 firm-year observation of large Japanese listed firms.

This study is anchored on the Four Pillars of Financial Sustainability Concept championed by Patricia León in 2001. The concept comprised of strategic and financial planning, sound administration and finance, income diversification, and own income generation. The concept posits that inefficient procedures for fiscal and strategic planning defeat financial sustainability. Private tertiary institutions, therefore, require the four pillars, like a table of four legs, to stand firmly.

\section{Conceptual Framework

Independent Variables

\section{Income Diversification:}

Dependent Variables

Financial Sustainability

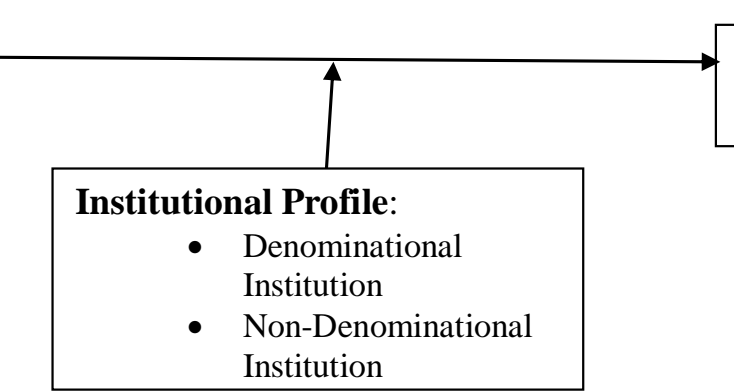

Figure 1. Conceptual Framework

\section{Methodology of research}

This study adopted a casual research design to study the correlation between income diversification and financial sustainability among private tertiary institutions. Among the institutions 14 (35\%) were denominational and 26 (65\%) were non-denominational. The study utilized parametric inferential statistics by relying on regression Process v3.2 by Andrew F. Hayes model 1.The study was carried out in private tertiary institutions in the Greater Accra Region of Ghana.40 out of the 60 private tertiary institutions in the Region were, randomly sampled to answer the self-constructed questionnaires with the Cronbach Alpha of .863 for income diversification and .852 for financial sustainability.

The items in the questionnaire were measured by using a 5-point Likert-type scale, based on Vagias's (2006) Likert scale recommendation, which ranged from Always-5, Often-4, Sometimes-3, Rarel-2 and Never-1. In ascertaining the strength of the relationship, Cohen (1998) absolute correlation values, where $r=.10$ to .29 means low, $r=.30$ to .49 means moderate and $r=.50$ to 1.0 , indicating high; were used. Ethical 
considerations for anonymity and confidentiality were considered in the distribution and in answering the question by the respondents.

\section{Results and discussions}

In the analysis, the study examined the relationship between income diversification and financial sustainability. The study revealed that there is a moderately positive significant relationship $(R=0.4195, p=$ 0.024 ) between income diversification and financial sustainability. This means that an increase in income diversification causes the PEls to become financially sustained. The study showed the co-efficient of determination to be $17.6 \%\left(R^{2}=0.1760\right)$, which indicates that income diversification can predict financial sustainability by $17.60 \%$. The implication of these results is that attainment of financial sustainability of private tertiary institutions moderately depends on income diversification. The study, therefore, reject the null hypotheses that there is no significant relationship between income diversification and financial sustainability of PTIs in the Greater Accra Region of Ghana as shown in Table 1. This result confirms Amos and Koda (2018) study in Tanzania among second cycle institutions, Ekpoh \& Okpa (2017) study in the South-South Region of Nigeria and Nyamwega (2016) study in Kenya among public secondary schools that income diversification reasonably contributes to the financial sustainability of PTIs.

Table 1. Model Summary

\begin{tabular}{lcccccccc}
\hline & $\mathrm{R}$ & $\mathrm{R}^{2}$ & $\mathrm{MSE}$ & $\mathrm{F}$ & $\mathrm{df1}$ & $\mathrm{df2}$ & $\mathrm{P}$ & $\mathrm{IV}$ \\
Model Summary & 0.4195 & 0.1760 & 0.1171 & 2.5623 & 3.0000 & 36.0000 & 0.0240 & $\mathrm{~S}$ \\
Interaction Model & & 0.0566 & & 2.4742 & 1.0000 & 36.0000 & 0.0450 & $\mathrm{~S}$ \\
\hline
\end{tabular}

S=Significant, NS= Not Significant

The final investigation for this research was to find out the moderating effect of institutional profile on the relationship between income diversification and financial sustainability of PTIs. The analysis of the impact of moderation is defined and submitted by following the model of Jose (2013), Haye (2009), and Hayes \& Matthes (2009). The influence of moderation, that is, an interaction effect, is perceived as either enhancing or antagonistic (Hayes \& Matthes, 2009). An enhanced moderation impact is when an increase in the quantity of the moderator (institutional profile) induces an increase in the impact of the independent variable on the dependent variable. An antagonistic impact is when an increase in moderator has a reverse effect on the independent variable. In the model for moderation, the denominational institutions were represented by 1 and the non-denominational institutions were represented by 2 . The initial summary model revealed a significant value of variance on financial sustainability $R^{2}=0.1760, F=2.562, p=.0240$. Then the interaction of financial sustainability and institutional profile was introduced. The moderating variable generated a significant change in the process having an interaction model of

$\Delta \mathrm{R}^{2}=0.0566, \Delta \mathrm{F}=2.4742, \mathrm{p}=0.0450$ as shown in Table 1 . In examining the interaction plot of institutional profile, figure 1 explains the moderation effect and the implication of income diversification on financial sustainability. It is noted that there is an enhancing effect of income diversification on financial sustainability because of the positive relationship with the introduction of institutional types interaction also increased, and it is statistically significant.

A detailed study, as shown in Table 2 on the significant moderation, also showed that most of the denominational PTIs rely on income diversifications the in their attainment of financial sustainability than non-denominational PTIs. The study reject the null hypothesis, which state that there is no significant moderating effect of institutional profile on the relationship between income diversification and financial sustainability when considering institutional type because the moderation interaction effect is statistically significant.

The result of this study is a confirmation of Sakawa (2020) study which found that institutional ownership has an enhancing effect on financial sustainability. Whereas, denominational institutions rely on income diversification to achieve financial sustainability, non-denominational institutions less rely on it. This implies that, income diversification strategies for financial sustainability of PTIs will vary between denominational and non-denominational tertiary institutions. 


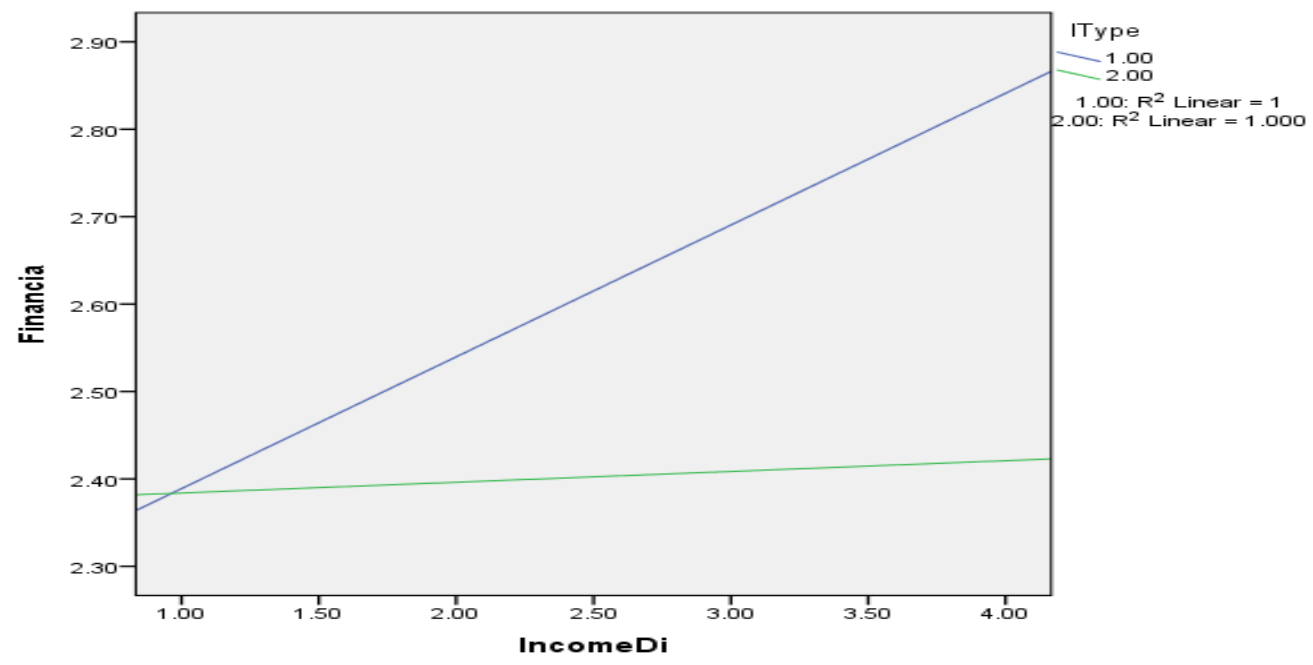

Figure 1. Enhancing the effect of institutional profile on the relationship between income

Diversification and financial sustainability of PTIs

\section{Conclusions and recommendations}

There was a moderately positive significant relationship between the income diversification and financial sustainability. This signifies an improvement in financial sustainability of PEls when the management put significant efforts into income diversification strategies. Income diversification could predict financial sustainability by $17.60 \%$. This study has shown that there is an enhancing effect of income diversification on financial sustainability of PTIs in the Greater Accra Region of Ghana when considering their institutional profile. The study concludes that financial sustainability of private tertiary institutions depends on income diversification strategies. The study, therefore, recommends that the PEls invest in profitable income diversification ventures. The study further recommends for future studies to identify the other $82.40 \%$ variables that can help to explain financial sustainability of PEls.

\section{References}

1. Adan, S. M., \& Keiyoro, P. (2017). Factors influencing the implementation of income generating projects in public secondary schools in Isiolo North Sub County, Kenya. International Academic Journal of Information Sciences and Project Management, 2(1), 558-573.

2. Addo, C. (2018). Central running on life support-Registrar. Retrieved from https://www.yen.com.gh/ 107277-central-university-running-life-support-registrar.html\#107277

3. Afriyie, A. O. (2015). Financial Sustainability Factors of Higher Education Institutions: A predictive model. International Journal of Education Learning and Development, 2(3), 17-38.

4. Agyeman, B. A. S., Asuming-Brempong, S., \& Onumah, E. E. (2014). Determinants of income diversification of farm households in the Western Region of Ghana. Quarterly Journal of International Agriculture, 53(1), 55-72.

5. Ahmed, S. (2015). Public and private higher education financing in Nigeria. European Scientific Journal, 11(7), 92-109.

6. Alhassah, I. (2018). Revise programmes to avoid collapse - NAB to Private Unis. Retrieved from https://starrfmonline.com/2018/03/revise-programmes-avoid-collapse-nab-private-unis/

7. Amos, O., \& Koda, G. M. (2018). Contribution of school-based income generating activities in quality education provision in secondary schools managed by the Catholic Diocese of Moshi, Tanzania. British Journal of Education, 6(4), 49-69.

8. Association of Chartered Certified Accountants Study Text. (2017). Financial Reporting. United Kingdom: BPP Learning Media.

9. Bediako, K. D. (2019). $25^{\text {th }}$ Congregation and $40^{\text {th }}$ Anniversary Celebration (Vice-Chancellor's Report). Valley View University 
10.Cernostana, Z. (2017). Financial sustainability for private higher education institutions. Paper presented at the Ninth International Conference on Applied Economics Contemporary Issues in Economy, Toruń, Poland.

11.Cernostana, Z. (2018). Measuring Financial Sustainability of Private Higher Education Institutions. Retrieved from https://www.tf.Ilu.Iv/conference/ procedings2015/Papers/ N343 .pdf

12.Citifmonline. (2018). Private universities on the verge of collapse.

13.de Jesus, D. S. V., \& Dubeux, V. J. C. (2018). The crisis in private higher education in Brazil: main causes and possible solutions. International Journal for Innovation Education and Research, 6(1), 35-46.

14.Dogbey, S. A. (2020). Ghana National Association of Private Schools pursues financial aid to pay salaries of teachers. Retrieved from https://www.myjoyonline.com

15.Donkor, E. A. (2017). Private universities facing financial challenges despite rebate - University President. Retrieved from https://www.myjoyonline.com/news/ 2017/ December-14th/privateuniversitiesfacing-financial-challenges-despite-rebate-university-president.php

16.Eide, S. (2018). Private colleges in peril. Retrieved from https://www.educationnext.org/ privatecolleges-peril-financial-pressures-declining-enrollment-closures/

17.Ekpoh, U. I., \& Okpa, O. E. (2017). Diversification of sources of funding university education for sustainability: Challenges and strategies for improvement. Journal of Education, Society and Behavioural Science, 21(2), 1-8. doi: 10.9734/JESBS/ 2017/ 34494

18.Esampally, C., \& Joshi, M. K. (2016). Operational self-sufficiency of select NBFC-MFIS of Andhra Pradesh. Retrieved from https://www.researchgate.net/publication/305309388

19.Funtahun, G. E., Sani, S., \& Kemaw, B. (2018). The role of income diversification on risk management and rural household food security in Ethiopia. Journal of Economics and Sustainable Development, 9(9), 15-24.

20.Ghana News Agency. (2017, November 12). Private universities face imminent collapse-Prof. Nsowah-Nuamah. Retrieved from https://www.myjoyonline. com/news/2017/ November-12th/privateuniversities-face-imminent-collapse-prof-nsowah-nuamah.php

21.Greenwill, B. (2017). Business strategies to increase the financial stability of private universities. Retrieved fromhttp://www.scholarworks. waldenu.edu/dissertations

22. Harelimana, J. B. (2017). The determinants of financial and operational sustainability of microfinance institutions: Case study of Clecam-Ejoheza Ltd. Global Journal of Management and Business Research,17(4), 32-44.

23.. Will half of all colleges really close in the next decade? Retrieved from https://www.forbes.com/sites/michaelhorn/2018/12/13/will-half-of-all-colleges-really-close-in-the-nextdecade/\#36381c7852e5

24.Hossan, M. S., \& Khan, M. A. (2016). Financial sustainability of microfinance institutions (MFIs) of Bangladesh. Developing Country Studies, 6(6), 69-78. Retrieved from https://www.pdfs.semanticscholar. org/e967/ 4a43bd2b51be263bbeb85e9281e46ad890ac.pdf

25.Ibrahim Y., Ahmed, I., \& Minai, M. S. (2018). The influence of institutional characteristics on financial performance of microfinance institutions in the OIC countries. Economics and Sociology, 11(2), 1935. doi:10.14254/2071-789X.2018/112/2.

26.ljeoma, M. M., Ezeamama, M., Ebisi, L. N. E. (2018). Economic Policy Management in Nigeria: Effective Diversification Approaches, International Journal of Academic Research in Accounting, Finance and Management Sciences 8 (4): 195-203.

27.Institute of Chartered Accountants Ghana Study Text. (2015). Management Accountant (1 $1^{\text {st }}$ ed.). Ghana: BPP Learning Media.

28.Khan, Z. A., Butt, S., \& Khan, A. A. (2017). Determinants of financial self-sufficiency in microfinance institutions: A study of Pakistan, India and Bangladesh. European Online Journal of Natural and Social Sciences, 692, 296-301.

29.Kharusi, S. A., \& Murthy, S. R. Y. (2018). Financial sustainability of private higher education institutions: The case of publicly traded educational institutions. Investment Management and Financial Innovations, 14(3), 25-38. dx. doi.org/10.21511/imfi.14(3).2017.03 
30.Kisengo, Z. M., \& Kombo, H. (2014). Effect of firm characteristics on performance of the microfinance sector in Nakuru, Kenya. International Journal of Science and Research, 3(10), 1791-1799. Retrieved from https://www.ijsr.net

31.Kolenda, N., \& Organisjana, K. (2015). Challenges in learning for company's financial viability assessment and management. Verslas: Teorija ir prakTika/Business: Theory and practice, 16(2), 195-204. Challenges_in_Learning_for_Company's_Financial_Viability_Assessment_and_Management

32.Krasulia, A. (2014). Endowment as an educational fundraising tool for entrepreneurial university:

The U.S. experience versus Ukrainian reality and perspectives. Retrieved from http://www.cejsh.icm.edu.pl/cejsh/element/bwmetal1.element.ojs-doi.../11086-10646.pdf

33.Lambinicio, J. S. (2016). Organizational Performance of Higher Education Institutions in Pangasinan. Paper presented at the Third Asia Pacific Conference on Applied Research, Melbourne. Retrieved from https://www.apiar.org.au/journal-paper-/organizational-performance-of-higher-educationinstitutions-in-pangasinan/

34.León, P. (2001). Four pillars of financial sustainability. Retrieved from http://www.ve.vhjdvbyz. vesrv.com/sites/default/files/documents/fundraising/four-pillars-financial-sustainability-tnc.pdf

35.Marginson, S. (2017). Global Trends in Higher Education Financing: The United Kingdom. International Journal of Educational Development. Retrieved from https://www. sciencedirect.com/ science/article/pii/S0738059 317301748

36.Miranda, T., Tenedero, L. E., Fiel-Miranda, J. L., \& Celestino, E. R. (2016). The income-generating project of a government academic institution in the Philippines: The case of the University of Eastern Philippines. Asia Pacific Journal of Innovation and Entrepreneurship, 10(1), pp. 5-16. doi/full/10.1108/APJIE12-2016-006

37.Mugo, A. N., \& Ngahu, S. T. (2015). Assessment of financial challenges affecting operations of private tertiary colleges in Nakuru town, Kenya. International Journal of Economics, Commerce and Management, 3(5), 1476-1486.

38.Mujani, W. K., \& Yaakub, D. I. (2017). Waqf for higher education in Malaysia: Overview on challenges. European Journal of Multidisciplinary Studies, 2(5), pp. 455-461.

39.Mynewsgh. (2018). Central university to sack over 200 staff in latest revelation. Retrieved from https://www.ghanaweb.com/GhanaHomePage/NewsArchive/Central-University-to-sack-over-200-staff- inlatest-revelation-631919

40.Njeri, W. R., Namusonge, G., \& Mugambi, F. (2017). Effect of working capital management on financial sustainability of Government Owned Entities in the Ministry of Agriculture, Livestock and Fisheries (MOALF), Kenya. The Strategic Journal of Business and Change Management, 4(3), 147 - 175.

41.Nyamwega, H. N. (2016). An evaluation of income generating projects in public secondary schools in Nairobi County. International Journal of African and Asian Studies, 21, 6-16.

42.Oduor, A. (2018). Looming crisis as public varsities face closure over debts. Retrieved from https://www.standardmedia.co.ke/article/2001301801/why-public-varsities-risk-closure-in-2019

43.Pavlov, O. V., \& Katsamakas, E. (2019).Financial sustainability of colleges as complex service systems. WPI SSPS Working Paper No. 2019-001.Retrieved from https://www. researchgate.net/ publication/334680477_Financial_Sustainability_of_Colleges_as_Complex_Service_Systems

44.Pop, I.-D. (2019). Systemic Sustainability of European Banking Activity: A Multi- Perspective Approach, International Journal of Academic Research in Accounting, Finance and Management Sciences, 9 (3): 54-63

45.Quartey, P. (2020). COVID-19 and the plight of private school teachers in Ghana. Statistical, Social and Economic Research.

46.Sakawa, H., \& Watanabel, N. (2020). Institutional ownership and firm performance under stakeholder-oriented corporate governance. Sustainability Journal, 12(3), pp. 1-21. Retrieved from https://www.doi.org/10.3390/su12031021

47.Salam, S., Bauer, S., \& Palash, S. (2019). Impact of income diversification on rural livelihood in some selected areas of Bangladesh. Journal of Bangladesh Agricultural University, 17(1), 73-79.

48.Sarafica, R. (2018). Private colleges to gov't: We need your help too. Retrieved from https://www.rappler.com/move-ph/198346-private-colleges-urge-government-support 
49.Siaw, E. K. (2018). Public universities crippling private universities. Retrieved from https://www.modernghana.com/news/897917/public-universities-crippling-private-universities.html

50.Stice, D., Stice, E. K., \& Stice, J. D. (2017). Cash flow problems can kill profitable companies. International Journal of Business Administration, 8(6), 46-54.

51.Vagias, W. M. (2006). Likert-type scale response anchors. Clemson International Institute for Tourism \& Research Development, Department of Parks, Recreation and Tourism Management. Retrieved from http://www.media.clemson.edu/cbshs/prtm/research/resources-for-research-page-2/Vagias-LikertType-Scale-Response-Anchors.pdf

52.Wachira, R. N. (2018). Financial sustainability determinants of Government Owned Entities in Kenya (Doctoral dissertation, Jomo Kenyatta University of Agriculture and Technology). Retrieved from http://www.ir.jkuat.ac.ke/bitstream/handle/123456789/ 4840/ Print\%20 Copy\%20final\%20thesis\%20\%20 Rosaly\%20N\%20_ONedits.pdf? sequence=1\&isAllowed=y

53.Water \& Sanitation for the Urban Poor. (2017). Balancing financial viability and user affordability: An assessment of six WASH service delivery models. Retrieved from https://www.wsup.com/content/uploads/2017/09/08-2017-Balancing-financial-viability-and-useraffordability-single-page.pdf

54.Wijewaradana, W. P., \& Munasinghe, P. G. (2015). Cash Flows and Firm Performance: Some Evidence from the Sri Lankan Firms Cash Flow. Journal of Management Matters, 2(1), 41-48.

55.Wu, F. H. (2017). The crisis of American higher education. Retrieved from https://www.tah. oah.org/february-2017/the-crisis-of-american-higher-education/

56.Yanka, K. (2017). Leadership for a changing public-private higher education landscape. A paper presentation at 2017 International Association of Universities Conference, Accra, Ghana. Retrieved from https://www.ug.edu.gh/sites/default/files/images/Address\%20 by\%20 Professor\%20Kwesi\%20 Yankah \%20\%20-\%20IAU\%202017\%20 INTERNATIONAL\%20 CONFERENCE.pdf 